\title{
Nordic Geoscience and the 33rd International Geological Congress: Introduction
}

\begin{abstract}
Geology has been of profound importance for the Nordic countries since the Middle Ages. Strong economies were built on an understanding of the occurrence in bedrock of minerals containing metals, e.g., silver, copper, zinc and iron, and eventually led to the establishment of the first Geological Surveys in Norway and Sweden in the middle of the nineteenth century. The geology of Norden ranges from the oldest to youngest rocks on the planet. Based on the papers in this special issue, this introduction provides a brief summary of the geological evolution of Norden, from the Archean of Greenland and northern Fennoscandia to the on-going volcanicity in Iceland on the MidAtlantic Ridge. It also refers to aspects of Geoscience that are particularly important for society in Norden, including geo-resources (petroleum, geothermal energy, nuclear energy, metals, industrial minerals and groundwater) and environmental geology (including natural and anthropogenic processes, medical geology, geo-hazards and climate). Information on the early history of geology in Norden and the geological surveys is also included and, finally, an outline of the 33rd International Geological Congress with its main theme "Earth System Science: Foundation for Sustainable Development”.
\end{abstract}

\section{Introduction}

This special issue of Episodes provides a summary of Geoscience in the Nordic countries: Denmark (including Greenland and the Faroe Islands), Finland, Iceland, Norway and Sweden. It has been designed as a background for and an introduction to the 33rd International Geological Congress (IGC) to be held in the Norwegian capital of Oslo in August 2008. The Congress itself is presented by the Secretary General and the President (Solheim and Bjørlykke, this volume). Nordic Geoscience is treated in two parts: the first focuses on the geology (stratigraphy, structure and tectonic evolution) of Norden, from the Archean to the Present, and the second concerns aspects of our science that are of particular importance for society. This paper presents a brief introduction to the other twenty-five papers in the volume, summarizing the geological history of Norden, the main topics of societal importance and the structure, main themes and other activities of the Congress.

\section{The geology of Norden}

The Nordic countries reach across the North Atlantic Ocean from the Scandinavian continental margin of western Eurasia, via Iceland (perched on the mid-ocean ridge) to the Greenland segment of Laurentia. The rocks range in age from the earliest Archean to the Present, and the plate tectonic environments from the accretional and collisional orogens of the Precambrian and mid Paleozoic to the Mesozoic extensional regimes of the continental shelves and the Cenozoic sea-floor spreading in the Atlantic. Climate cooled in the latter part of the Cenozoic and the Quaternary history includes repeated cycles of glaciation and deglaciation prior to Holocene warming and migration of Homo sapiens into the Arctic.
Norden's oldest rocks occur in the Archean/Paleoproterozoic basement of Greenland, and the Fennoscandian (Baltic) Shield. Early Paleozoic successions overlie these cratons, largely undisturbed, except in the Caledonides. This orogen flanks northeastern Greenland and western Scandinavia, continuing northwards via Svalbard to the edge of the Arctic Ocean. Latest Paleozoic, Mesozoic and Tertiary strata are mainly preserved off-shore on the continental shelves, outcropping on land in southern Scandinavia, northeast Greenland and Svalbard.

The oldest known rocks deposited on the surface of the Earth are found in the dominantly Mesoarchean craton of southwest Greenland (Hölttä, Balagansky, Garde, Mertanen, Peltonen, Slabunov, Sorjonen-Ward, and Whitehouse, this volume). The c. 3.86-3.6 Ga assemblages comprise of pillow lavas, banded-iron formations and metasedimentary rocks with graphite, possibly of biogenic origin. The Mesoarchean crustal terranes in Greenland amalgamated at c. $2.7 \mathrm{Ga}$. Mesoarchean rocks are also found in the northern part of the Karelian Province of the Fennoscandian shield, but 2.9-2.7 Ga TTG orthogneisses and greenstone belts dominate. Eclogites and Iringora supra-subduction ophiolite occur in eastern Fennoscandia, indicating that subduction-related processes were active in the Neoarchean.

During the Paleoproterozoic, Fennoscandia experienced a long period $(2.5-2.1 \mathrm{Ga})$ of multiphase intraplate rifting. This was followed (2.1-2.04 Ga), both in Fennoscandia and Greenland, by drifting and separation of Archean cratons and formation of new oceans (Lahtinen, Garde, and Melezhik, this volume). The Lapland-Kola orogen $(1.94-1.86 \mathrm{Ga})$ in Fennoscandia, and the Inglefield mobile belt $(1.95-1.92 \mathrm{Ga})$ and the Rinkian fold belt/Nagssugtoqidian orogen $(1.88-1.83 \mathrm{Ga})$ in Greenland are continent-continent collision zones with limited formation of new crust, whereas the Ketilidian orogen (c. $1.8 \mathrm{Ga}$ ) in South Greenland displays a convergent setting without sub-

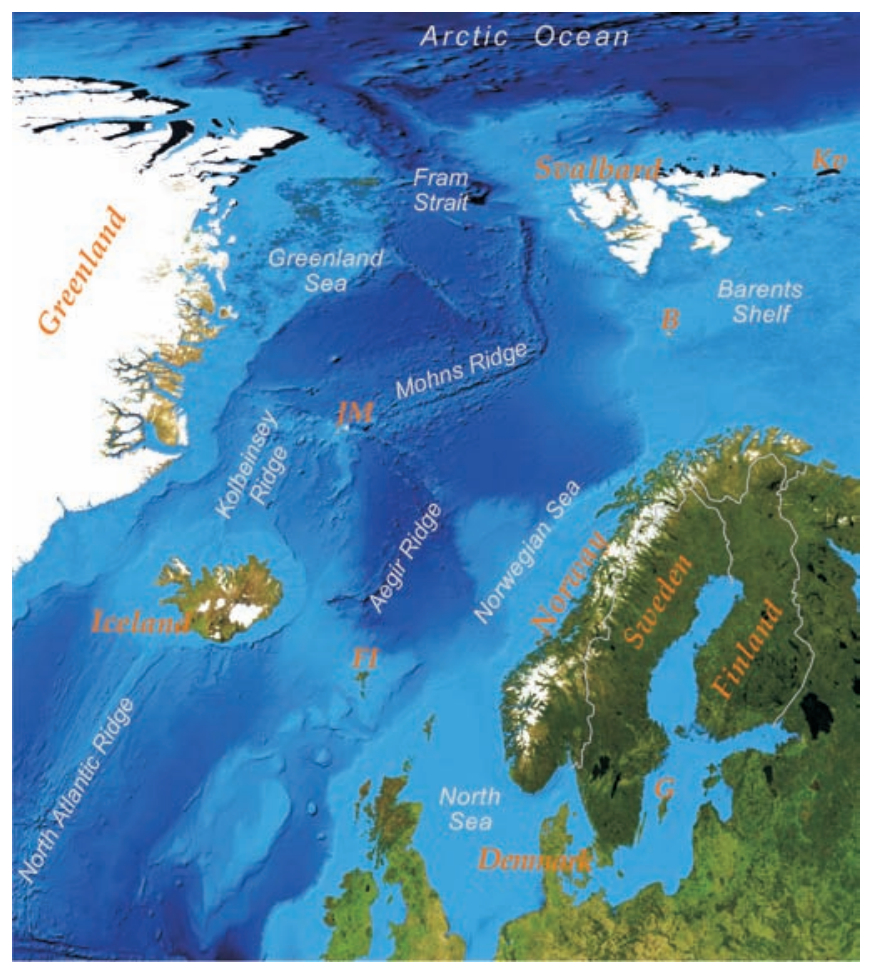

Figure 1 Norden from the Blue Marble map (Stöckli et al., 2001). Abbreviations refer to: Bjørnøya (B), Faroe Islands (FI), Gotland (G), Jan Majen (JM), Kvitøya (Kv). 
sequent collision. The composite Svecofennian orogen $(1.92-1.79 \mathrm{Ga})$ is a collage of 2.1-2.0 Ga microcontinents and 2.02-1.82 Ga island arcs attached to the Archean Karelian craton and responsible for the main Paleoproterozoic crustal growth of Fennoscandia.

Mesoproterozoic tectonic activity in Greenland and central Fennoscandia is seen in the episodic occurrence of rapakivi granites and continental rift-related magmatic and sedimentary rocks (Bingen, Andersson, Söderlund, and Möller, this volume). The southwestern active margin of Fennoscandia experienced the Gothian $(1.64-1.52 \mathrm{Ga})$ and Telemarkian $(1.52-1.48 \mathrm{Ga})$ accretionary events, and the Hallandian-Danopolian (1.47-1.42 Ga) event affected southern Fennoscandia. The interval between 1.34-1.14 Ga was characterized by bimodal magmatism and sedimentation and followed by the Sveconorwegian orogeny (1.14-0.97 Ga), involving polyphase terrane accretion during collision between Baltica and another major plate. Alternative models for restoring the Sveconorwegian and Grenville (Laurentia) belts at $1.0 \mathrm{Ga}$ are discussed, and the "classical interpretation", involving correlation of the E-vergent thrust system in the former with the $\mathrm{W}$-vergent in the latter, is favored.

Much of the Neoproterozoic history of the Nordic countries is preserved within the Caledonide Orogen in the mountains of western Scandinavia, eastern Greenland and the Svalbard archipelago (Nystuen, Andresen, Kumpulainen, and Siedlecka, this volume). The various Caledonian allochthons provide evidence of three hundred million years (from c. 900 to $600 \mathrm{Ma}$ ) of rifting and extension, following the collapse of the Grenvillian-Sveconorwegian Orogen and accompanying the break-up of Rodinia. The Neoproterozoic sedimentary successions of the Laurentian margin, and partly also the Baltoscandian margin, are characterized by thick siliciclastic formations, overlain by limestones, dolomites and Vendian tillites. Palinspastic reconstruction of the Caledonian thrust-sheets suggests that they were deposited at least in part on continental crust of Mesoproterozoic age, now submerged beneath the Greenland and Norwegian seas and the Barents shelf.

By the beginning of the Phanerozoic, the Precambrian cratons of Laurentia and Baltica were separated by an expanding tract of oceanic crust (Gee, Fossen, Henriksen, and Higgins, this volume). Sedimentation on the Laurentian platform was dominated by CambroOrdovician carbonates, characteristic of the low latitude environments that reached from the northern Appalachians to Svalbard. Baltica lay at higher latitudes and was dominated by siliclastic deposition, particularly of kerogen-rich (alum) shales in the Cambrian and carbonates and shales in the Ordovician and Silurian. The Iapetus Ocean, separating Baltica from Laurentia, started closing early in the Ordovician and the continents collided in the early-mid Silurian, with the onset of Caledonian (Scandian) Orogeny. The resulting orogen is now exposed on both sides of the North Atlantic, with W-vergent thrust systems in eastern Greenland and E-vergent in western Scandinavia. Underthrusting of Laurentia by Baltica culminated in the early Devonian with rapid exhumation of the hinterland and collapse of the mountain belt, with extensional faulting and deep erosion.

Further south in Europe, orogeny continued into the late Paleozoic in the Variscides, during the final assembly of the Pangea megacontinent, and was followed by Permian rifting. The latter extended northwards into southern Scandinavia, where rifting, starting in the latest Carboniferous, was particularly prominent in the Caledonian front of the Oslo area (Larsen, Olaussen, Sundvoll, and Heeremans, this volume). Extensional faulting and igneous activity in this major graben lasted through the Permian into the early Triassic, with widespread volcanism, well-preserved calderas and major batholiths, now excellently exposed in the surroundings of Norway's capital.

During the Mesozoic, Pangea began to fragment and the parts that are now found in Norden drifted northwards from equatorial to temperate climate zones (Nøttvedt, Johannessen, and Surlyk, this volume). Northern (Boreal) and southern (Tethys) oceans were separated by a land-bridge between Scandinavia and Greenland in the Triassic and the successions are characterised by numerous marine transgressions and regressions. Sea-level rise in the latest Triassic resulted in widespread deposition of siliclastics in shallow marine shelf and deltaic environments in the Early and Middle Jurassic. A major phase of extension and rifting occurred in the Late Jurassic and Early Cretaceous and sea-level rise drowned the land barrier between Scandinavia and Greenland; marine shales with highly kerogen-rich intervals were deposited over vast areas of what are now the Nordic continental shelves. Sea level continued to rise during the Cretaceous with deposition of several kilometres of deep water shales, marls and sands in the deepest basins. Shallow marine and coastal plane deposits dominated on the flanking platforms, extending far onto the ancient land areas of southern Scandinavia towards the end of the period.

Latest Cretaceous and earliest Tertiary rifting in the North Atlantic led to continental break-up between Scandinavia and Greenland in the Late Palaeocene/Early Eocene. This event was associated with regional uplift of the whole of the Norwegian and Greenland seas and adjacent areas, creating an emergent platform along the axial rift zone. The general uplift drastically reduced the size of the basins and expanded the hinterland areas, effectively ending carbonate deposition; the whole region became dominated by marine siliclastics (Rasmussen, Heilmann-Clausen, Waagstein, and Eidvin, this volume). The final rupture of the continental crust in the latest Paleocene/earliest Eocene, was accompanied by the eruption of vast volumes of tholeiitic flood basalts within the axial area, which spread across the whole of the eroded platform. Thereafter, the newly established spreading axis and surrounding lava platforms started to subside and eventually submerged below sea-level.

At the same time as the extension, rifting, volcanism and eventual separation of Greenland from Scandinavia was going on, the western margin of the Barents Shelf was forming along a major transcurrent shear-zone, the De Geer fracture zone. Svalbard moved dextrally from a position north of Greenland in the Mesozoic towards its present position, with the opening of the Greenland Sea, eventually establishing a connection to the Arctic Basin via the Fram Straits. During translation along the De Geer fracture zone, past the northeastern end of Greenland, western Svalbard was influenced by Paleocene transtension, Eocene transpression (with the formation of the West Spitsbergen fold and thrust belt) and subsequent Oligocene oblique separation and rifting.

The opening of the ocean between Scandinavia and Greenland was initially accomplished along a spreading axis (the Aegir Ridge) now located to the east of Iceland. At the end of the Oligocene, the spreading ridge jumped westwards to the presently active Kolbeinsey Ridge, north of Iceland, separating a sliver of continental crust off East Greenland. This subsequently became the Jan Majen microcontinent, at the southern end of which Iceland started to grow.

The composition and structure of the North Atlantic sea floor, dominated by oceanic crust formed at the Mid-Atlantic Ridge, differs greatly from the adjacent continental margins. Iceland is the only large sub-aerial exposure of the ridge. With its surface rocks younger than $15 \mathrm{Ma}$, it offers unique possibilities to observe the processes that form oceanic crust (Sigmundsson and Sæmundsson, this volume). Iceland hosts over 30 active volcanic systems of different character, with long fissure eruptions and diking events contributing to the tectonic and magmatic processes of plate spreading. The geological record in Iceland also holds important information on the paleo-climate of the North Atlantic and the interplay of volcanicity and glaciation during the Quaternary.

The profound differences in character of the Nordic continental margins, from the extended, rifted, passive margins between Scandinavia and Greenland in the south to the De Geer fracture zone in the north, are clearly defined in the deeper crustal structure (Faleide, Tsikalas, Breivik, Mjelde, Ritzmann, Engen, Wilson, and Eldholm, this volume). The continental basement of western Scandinavia thins irregularly westwards far out beneath the shelf to the continent-ocean boundary. In the lowermost crust of the outer shelf and ocean boundary zone, a several kilometre thick unit of high P-wave velocity $(7.3-7.6 \mathrm{~km} / \mathrm{sec})$ is located beneath the area of break-up volcanicity, apparently related to this magmatic event. Further north and in striking contrast, the relatively thick Barents Shelf basement is truncated abruptly along the narrow De Geer fracture zone and the lower crustal high-velocity body is only present locally near Bjørnøya. 
During the Oligocene and Miocene, sedimentation on the continental margin was typical of a marine, subsiding passive margin, overprinted by intermittent regional phases of tectonic movement and uplift. In general, the Miocene and Pliocene provide a record of deteriorating climate with oscillating glaciations, which strongly influenced the sediment supply to the shelf, particularly towards the end of the Pliocene and in the Pleistocene. The onset of major glaciations at c. 2.7 Ma, led to deep erosion of the Scandinavian mainland and the deposition of huge sediment volumes on the adjacent shelves. Uplift of the mainland and the Barents Sea areas, due to both tectonic processes and an isostatic response to erosion, continued into the latest Pliocene and was accompanied by the progradation of major sediment aprons onto the continental margins. The largest sediment volumes are found in fans, several kilometres thick, adjacent to major submarine channel systems, e.g., northeast of Kvitøya (easternmost Svalbard), west of Bjørnøya, and in the Møre Basin area at the mouth of the Norwegian Channel.

Much of the younger Quaternary history has been obscured by the advance and retreat of the last glaciation (Weichselian), which lasted for about a hundred thousand years (Wohlfarth, Björck, Funder, Houmark-Nielsen, Ingólfsson, Lunkka, Mangerud, Saarnisto, and Vorren, this volume). The previous short interglacial (Eemian) apparently experienced temperatures as much as $5{ }^{\circ} \mathrm{C}$ higher than today, with ice-caps like those on Greenland reduced to about half their size and sea-level correspondingly higher. At its maximum, the Weichselian ice sheets occupied much of Norden and those on Greenland extended far westwards through northern North America. Weichselian deglaciation started about seventeen thousand years ago and about ten thousand years later the icecaps and glaciers had retreated to about where they are today. The sudden increase in temperature driving the deglaciation reached a few degrees higher than today and, despite interruptions, persisted to a thermal optimum in the early-mid Holocene, prior to the last five thousand years of irregular slow cooling. Retreat of the Weichselian ice sheets led to isostatic uplift, which continues today in central parts of Norden.

Throughout Earth's history, the planet has been influenced by extraterrestrial phenomena and processes, such as the variations in solar irradiation due to changing orbital paths around the sun, and the impact of meteorites and larger bolides. The importance of impact structures for the geological evolution and for life on the planet has been recognized increasingly during the last twenty years, particularly with the identification of the major Chicxulub impact at the Cretaceous-Tertiary boundary and its influence on the biosphere (Dypvik, Plado, Heinberg, Håkansson, Pesonen, Schmitz and Raiskila, this volume). In Norden, Europe's largest and most deeply investigated impact crater (drillholes to 6-7 km) is found in the Siljan lake area of central Sweden. Many other impact craters have been identified in the Nordic countries, some of probable Precambrian age; most, however have been found in sedimentary bedrock, ranging in age from the Neoproterozoic to the Late Mesozoic. Even the far distant effects of the Chicxulub impact are well displayed in Norden, in Denmark's famous Stevns Klint locality.

The long history of crustal growth, outlined above, and the eventual fragmentation of Pangea, with opening of the North Atlantic Ocean, are reflected in the character of the deep crust and upper mantle (Artemieva and Thybo, this volume). The continental lithosphere of Fennoscandia and Greenland is about 200km thick and the crust in the former is some of the thickest on the planet (c. $60 \mathrm{~km}$ ) for old Precambrian cratons. Both the crust and lithospheric mantel thin towards the continent-ocean boundary and the North Atlantic Ocean. Interpretation of the deep structure beneath Iceland, located on the Mid Atlantic Ridge, is proving highly controversial, with some authors favouring an abnormally thick (c. $30 \mathrm{~km}$ ) oceanic crust and others inferring thin $(10-15 \mathrm{~km})$ crust beneath the rift axis and thickening to $30 \mathrm{~km}$ on the adjacent Iceland-Faroe and Iceland-Greenland ridges. A plume beneath Iceland has been inferred by many authors, based on surface wave tomography, but even this interpretation is not uncontroversial.

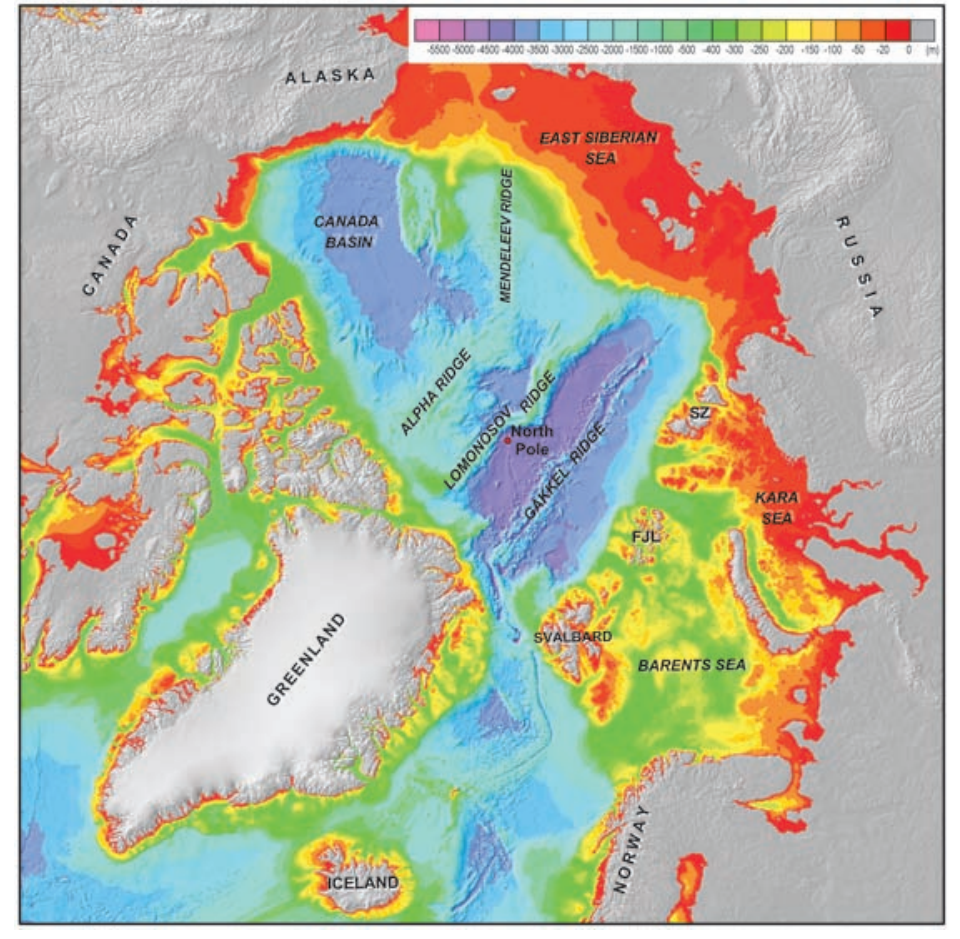

Figure 2 Simplified edition of the International Bathymetric Chart of the Arctic Ocean (Jakobsson et al., 2000). Abbreviations refer to: Franz Josef Land (FJL) and Severnaya Zemlya (SZ).

\section{Geoscience for society}

The importance of Geoscience for society in the Nordic countries is illustrated in this volume by a set of papers that range from the georesources in the different countries to the importance of environmental studies (particularly in the context of toxic substances), the impact of natural hazards and the significance of climate change. The history of Geoscience in Norden is also treated, along with some examples of the activities of the different geological surveys.

The importance of petroleum for the economies of Norway and Denmark became apparent in the 1960's. The discovery of the Groningen Gas Field in the Netherlands in 1959 triggered interest in also exploring the offshore areas of the North Sea (Spencer, Briskeby, Christensen, Foyn, Kjølleberg, Kvadsheim, Knight, Rye-Larsen, and Williams, this volume). Through the 1960 `s, the continental shelf boundaries in the North Sea were established, and the first licensing rounds in Norway, Denmark and U.K. were announced. Oil was discovered by the Møller Group already in 1966 in Danish waters and by Esso in the Norwegian waters in 1967, but at the time, they were not regarded as commercial. The first commercial oil discovery, the Ekofisk Field with a Danian chalk reservoir, was discovered in 1969 and put in production in two years later. 1971 also saw the discovery of the extremely important Brent Oil Field, with a Middle Jurassic sandstone reservoir, made by Shell in U.K. waters. The Brent discovery led to the subsequent discoveries of the "Jurassic elephants" of the Norwegian North Sea, e.g., Statfjord, Gullfaks, Oseberg, and Troll. In 1980 , exploration also moved north of $62^{\circ} \mathrm{N}$ into the Norwegian Sea and the Barents Sea. Since the start in the 1960's, these four regions - the Danish and Norwegian North Sea sectors, the Norwegian Sea and the Barents Sea-have seen the great majority of all the exploration in Norden: about 850 wildcat wells, resulting in about 300 oil and gas finds. Offshore West Greenland and onshore Svalbard have also seen some exploration drilling, but without any discoveries. Exploration drilling has also taken place in southern Sweden and in the adjacent Baltic Sea, leading to very small discoveries on the Island of Gotland only. In the Faroe Islands, where exploration started in 2001, one oil discovery has been made so far. 
Interest in geothermal energy, as with other renewable energy sources, is increasing rapidly in the Nordic countries. Heat pumps are widely used for space heating in Sweden. However, Iceland, thanks to its young volcanic bedrock and associated high-thermal gradients, is the only Nordic country where geothermal energy can be used to produce electricity (Lund, Bjelm, Bloomquist and Mortensen, this volume). Numerous high-temperature geothermal areas are found at the main volcanic centres on Iceland, where intrusions provide a heat source. Extensive fracturing of the bedrock facilitates the flow of water through the upper crust, resulting in widespread, relatively low-temperature geothermal sources over much of the country. Ninety percent of the houses on Iceland are heated with geothermal energy.

One of the most important sources of energy in Sweden and Finland is nuclear. Hydro and nuclear power provide most of Sweden's electricity and Finland is expanding its nuclear base with two new reactors. The highly toxic waste from these reactors is in interim storage, awaiting the construction of repositories at c $500 \mathrm{~m}$ depth in the crystalline bedrock (Milnes, Stephens, Wahlgren and Wikström, this volume). Both in Sweden and Finland, a similar design has been promoted and Finland is at present building a repository. Secure storage of the radioactive waste in a stable environment is essential, independent of whether or not future generations decide to exploit it further for energy production. Our understanding of the Fennoscandian Shield down to depths of a kilometre has been greatly improved by the wide range of studies of the crystalline bedrock, the Quaternary history and the hydrogeology required for the siting of these repositories.

Mining of metals in the Nordic countries has a long tradition. Documented mining dates back to the 8th century AD and, historically, mining has contributed substantially to the growth and welfare of the Nordic countries. Today this region is one of the most important metallic mining districts of the European Union. Metals are produced from active mines in all countries except Iceland and related industries are thriving (Weihed, Eilu, Larsen, Stendal, and Tontti, this volume). The historical production of metals was dominated by iron, copper and silver. Currently important ore deposit types include: volcanogenic massive sulphide deposits $(\mathrm{Cu}, \mathrm{Zn}, \mathrm{Pb}, \mathrm{Au}, \mathrm{Ag})$, orogenic gold deposits $(\mathrm{Au})$, layered intrusions $(\mathrm{Ni}, \mathrm{PGE}, \mathrm{Ti} \pm \mathrm{V})$, intrusionhosted $\mathrm{Cu}-\mathrm{Au}$, apatite-Fe deposits, and anorthosite-hosted $\mathrm{Ti}$ deposits. Besides these well-documented deposits, new kinds of deposits are being explored, e.g., iron oxide-copper-gold (IOCG) and shale-hosted $\mathrm{Ni}-\mathrm{Zn}-\mathrm{Cu}$ and different types of uranium deposits.

A number of different types of dimension stones are quarried in all the Nordic countries, some of which are world famous, such as the Nowegian Larvikite and the Finnish Rapakivi granites (Johansson, Larsen, Lehtinen, Persson, Räisänen, Schack Pedersen, Weihed, and Wik, this volume). Rock aggregates are increasingly important, replacing sand and gravel aggregate as construction materials in some countries due to the need to protect ground water supplies. The industrial minerals sector is expanding in most Nordic countries and extensive development has taken place during the last few years. The main commodities mined are carbonate rocks, quartz, feldspar, apatite, olivine and talc.

Access to drinking quality ground water is normally not a problem in the Nordic countries, which are characterized by many types of aquifers and great differences in groundwater recharge (Knutsson, this volume). Fracture zones in crystalline bedrock provide the most common type of aquifer. Porous aquifers are found in various types of rocks and soils. The most productive are the lava-fields and the pyroclastic rocks in the active volcanic zone of Iceland, but glaciofluvial deposits such as eskers and deltas in Finland, Norway and Sweden, outwash plains in southwestern Denmark and sandurs in Iceland are also very porous. Fractured porous aquifers in consolidated limestones and sandstones are common in Denmark and Scania in southernmost Sweden. Karst aquifers exist in the Caledonian mountain range in Norway and Sweden. Geothermal water with many springs and geysers are common in Iceland and of great economic importance.

Environmental geology, with particular concern for the mining environment, medical geology and urban geochemistry, is a scien- tific discipline that has developed strongly during recent years in the Nordic countries (Salminen, Kousa, Ottesen, Selinus, Steinnes, Tarvainen, and Öhlander, this volume). In mining environmental studies, methods that are suitable in Arctic conditions have been developed; in medical geology, the input from the Nordic countries has made it an appreciated scientific discipline throughout the world, and in the case of the urban environment, methods developed by geochemists have notably improved the health conditions.

Climate in Norden is much influenced by the Gulf Stream, with warm Atlantic waters from low latitudes being driven northwards along the west coast of Scandinavia into the high Arctic; a complementary current transfers colder waters from the Arctic Basin southwards along Greenland's east coast. Climate variability and change is particularly pronounced in the Arctic, with profound impact on the Nordic countries (Thiede and Johanesson, this volume). A thousand years ago, the Vikings were able to migrate to Iceland and then Greenland, only to be forced out of Greenland by the Little Ice Age, a few hundred years later. Studies of ice-cores from the Greenland ice-cap have shown that the last hundreds of thousands of years were dominated by long glacial periods interrupted by short interglacials (apparently driven by orbital forcing); the glacials also experienced repeated short-lived warming events with rapid changes in temperature. The climate record remains enigmatic and the anthropogenic influence difficult to quantify.

The relatively stable, old bedrock beneath most of the Nordic countries (Iceland excepted) provides an environment that is less susceptible to some of the major geohazards (e.g., earthquakes) that are experienced in so many other countries (Nadim, Asbjørn, Pedersen, Schmidt-Thomé, Sigmundsson, and Engdahl, this volume). Nevertheless, all the Nordic countries are prone to floods and landslides and, with the exception of Denmark, snow avalanches; the economic consequences can be severe. Building on quick sands, quick clays and mountain sides has proved particularly hazardous in Sweden and Norway. Slide-triggered tsunamis (e.g., in fjords) are also of concern, and research on large submarine slides on the continental shelf has been of importance for the petroleum industry. In Iceland, volcanic eruptions are frequent and the country's short history is scarred by many eruptions that have claimed lives; earthquakes of magnitude M7 can be expected every century. With regard to the other Nordic countries, Norway ranks highest in terms of earthquake hazards, with one M7-earthquake expected every 1,100 years. Relatively low population density in the geologically hazardous parts of the Nordic countries has implied that human losses have been fewer due to geohazards than in many other parts of the world.

Studies in the Earth Sciences have a long tradition in Norden, and in the eighteenth century Nordic scholars were in the forefront in chemistry, mineralogy and paleontology (Sundquist, Haapala, Hansen, Hestmark and Steinthorsson, this volume). This was also the century when "geology" started to be taught at the universities. In the ninteenth and twentieth centuries, state geological surveys, geological societies, journals and university chairs were established. Nordic geoscientists have contributed greatly to geology, e.g., in petrology, mineralogy, geochemistry, glacial geology, paleontology, stratigraphy, structural geology and geophysics. In more recent years, geology related to the energy issue has been much in focus in the Nordic countries.

The Nordic geological surveys have brought together information on the geology and natural resources of their respective countries for 150 years. The collective mission of the surveys in our time is to focus on "geology for society" by doing research and providing services, and by making the data easily accessible to the public. The paper by Smelror, Ahlstrøm, Ekelund, Hansen, Nenonen and Mortensen (this volume) gives a brief overview of some research areas and projects currently undertaken by the Nordic geological surveys. These serve as practical examples of how the surveys address important societal problems and challenges that require geological input for their solution. 


\section{The Congress programme}

As with previous International Geological Congresses, the programme for the 33rd IGC has been designed to cover as wide a range of the geosciences as possible. To emphasize the interdependence of the many disciplines in Geology, sensu lato, including geophysics, geochemistry, biogeology and classical geology, the Oslo Congress has been given the informal title "Geoscience World Congress 2008". And to highlight the increasing awareness worldwide of the importance of integrated Earth Science for society, the main theme of the 33rd IGC has been defined as: "Earth System Science: Foundation for Sustainable Development".

At the Oslo IGC, global issues of particular societal importance will be explored in plenary sessions as so-called "Themes of the Day". They will range from the origin and evolution of life on Earth and in a planetary context, to the supply of essential geo-resources, such as water, minerals and fossil fuels, and environmental and health-related issues, including climate change and geohazards. By combining the latest science with related economic and political presentations and encouraging interdisciplinary interaction and debate, IGC will provide an up-to-date assessment of the present status on these issues. The importance of interdisciplinary interaction in Earth System Science will be emphasized. Our science needs a fully integrated approach on all societal issues.

Major international projects such as the International Year of Planet Earth and the International Polar Year are highlighted in the "Themes of the Day" and the Arctic-Antarctic sessions, respectively. The Nordic countries reach far to the north into the high Arctic. Increased temperatures in recent decades and accompanying reduction in the regional distribution and thickness of the sea ice, particularly during summer months, has focussed interest both on the sensitive Arctic environment and also on the possible exploitation of the Arctic's natural resources. The northern sea-route from the Pacific (via the Bering Straits) to the North Atlantic (via the Kara Straits), pioneered by Nordenskiöld in the late nineteenth century, is beginning to look more like an opportunity than just a daunting challenge. Discoveries of hydrocarbons beneath the Barents and Kara seas are stimulating new surveys over the less hospitable shelves further east. They are also promoting a greater interest in the Arctic Basin itself, with its ridges and deep troughs (Figure 2). Jurisdiction over the continental shelves, out to the continent-ocean transition zone, is governed by the United Nations Convention on the Law of the Sea (UNCLOS, 1982). The 33rd IGC will provide a forum for review of the wide range of geoscientific research that has been going in this context since the 1980's.

Excursions are also in important part of the Congress programme. About thirty pre- and post-Congress excursions are in the programme for the 33rd IGC. Not all are fully booked and a few additional participants are welcome. The excursions will be run in all five Nordic countries, including Greenland and the Faroe Islands; also in Russia and Ukraine. Excursions 2, 9, 44 and 56 deal with onshore analogues to the Late Palaeozoic, Mesozoic and Tertiary geology of the continental shelves. Excursions 4 and 5 are dedicated to the past and present tectonic development and the general geology of Iceland. Excursions 6 and 7 deal with the volcanic stratigraphy and the glacial history, respectively, of the Faroe Islands. Excursions 12, 15, 47 and 48 cover the classical Precambrian ore deposits of Scandinavia and the Kola Peninsula, while Excursion 54 deals with the genesis of mineral deposits in the Urals. Excursions 16, 18, 42 and 51 are dedicated to the Precambrian geology of Scandinavia including the Sederholm migmatites in Finland and the Neoproterozoic glaciation facies exposed in Finnmark. A related excursion to the Ukrainian Shield is offered as No. 52. Paleozoic foreland geology and Late Paleozoic rift geology of southern Norway and Sweden are dealt with by Excursions 23, 24, 25 and 50. A related excursion, No. 10, deals with Paleozoic impact craters. Three excursions, Nos. 28, 29 and 34, offer transects of the Scandinavian Caledonides. Excursions 21 and 26 present recently established Norwegian geoparks, of which the first one already has the status of a UNESCO
European Geopark. Aspects of Quaternary geology are presented in excursions 11A, 11B, 39 and 40. A special excursion on issues related to disposal of nuclear waste is offered as No. 14. In addition to these pre- and post-Congress excursions there will be several one-day excursions offered, covering topics like classical fossil localities, paleo-impact craters, Neoproterozoic basin development, Paleozoic geology of the Oslo area, urban geology, and geothermal energy.

Proposals for twenty-two Workshops and ten Short Courses were accepted for inclusion into the science programme (a few of these have been later withdrawn or diverted into symposia). The workshops are arranged by individuals as well as organizations and represent a variety of themes, dealing with issues ranging from geoscience information and education, the future role for geoscientists in society and on the labour market to various problems of scientific character, like stratigraphic classification, paleontological data analysis and geochemical and risk mapping. The short courses are given by individuals, dealing with, e.g., airborne exploration geophysics, medical geology and mineralogy, paleoseismology, source rock modelling and numerical modelling in Earth sciences.

The International Geological Congress after 2008 in Norden, will be held in Australia. Towards the end of the 33rd IGC, a special symposium on Oceania will provide the backcloth for an invitation to join the 34th IGC in Brisbane in 2012.

\section{References}

For references to this issue of Episodes, see Contents List.

Jakobsson, M., Cherkis, N.Z., Woodward, J., Macnab, R. and Coakley, B., 2000. New grid of Arctic bathymetry aids scientists and mapmakers. Eos, Transactions, American Geophysical Union, v. 81, no. 9, p. 89, 93, 96.

Stöckli, R., Vermote, E., Saleous, N., Simmon, R. and Herring, D., 2005, The Blue Marble Next Generation - A true color earth dataset including seasonal dynamics from MODIS http://earthobservatory.nasa.gov/Newsroom/BlueMarble/bmng.pdf.

\section{David G. Gee}

Department of Earth Sciences,

Uppsala University,

Villavägen 16, SE-752 36, Uppsala, Sweden.

E-mail:david.gee@geo.uu.se

\section{Harald Brekke}

Norwegian Petroleum Directorate,

$\mathrm{Pb}$ 600, 4003 Stavanger, Norway.

\section{Raimo Lahtinen}

Geological Survey of Finland,

P.O. Box 96, FIN-02151 ESPOO, Finland.

\section{Freysteinn Sigmundsson}

Nordic Volcanological Center, University of Iceland, IS-101 Reykjavik, Iceland.

\section{Björn Sundquist}

Department of Earth Sciences,

Uppsala University,

Villavägen 16, SE-752 36, Uppsala, Sweden.

\section{Hans Thybo}

Department of Geography and Geology,

University of Copenhagen,

DK-1350 Copenhagen K, Denmark.

\section{Pär Weihed}

Division of Ore Geology,

Luleå University of Technology,

SE-971 87 Luleå, Sweden. 